\title{
PARTISIPASI MASYARAKAT DALAM MUSYAWARAH PERENCANAAN PAEMBANGUNAN DI DESA SIPODECENG KECAMATAN BARANTI
}

\author{
Reski Handayani \\ Prodi Administrasi publik fakultas ilmu sosial dan ilmu politik \\ Universitas Muhammadiyah Sidenreng Rappang \\ Reskihandayani790@gmail.com
}

\begin{abstract}
ABSTRAK
Tujuan penelitian ini untuk mengetahui partisipasi masyarakat dalam ,musyawarah perencanaan pembangunan di desa sipodeceng kecamatan Baranti . jenis pendekatan ini adalah metode deskriptif dengan pendekatan kualitatif dengan mengunakan aplikasi Nvivo .Adapun populasi dalam penelitian berjumlah 1637 kepala keluarga Teknik penarikan sampel yang digunakan adalah non porobability sampling yaitu dengan purposive sampling dengan Teknik pengumpulan melalui observasi ,dan study literatur review (libray research) Pendekatan yang digunakan pada penelitian ini yaitu dengan menggunakan pendekatan literature. Dalam melakukan pengumpulan data penelitian mengumpulkan data dan sumber informasi yang berhubungan dengan melalui data data pendukung yang bersumber dari jurnal penelitian ,artikel,buku-buku penunjang, surat kabar dan majalah,ulasan ,rangkuman dan pemikiran penulis tentang beberapa sumber Pustaka.
\end{abstract}

Kata kunci :partisipasi masyarakat ,musrenbang

\section{A. PENDAHULUAN}

Partisipasi masyarakat dapat diartikan sebagai bentuk keterlibatan masyarakat yang memiliki tujuan dan kebutuhan yang sama dalam pengambilan keputusan yang mempengaruhi kehidupannya. Pengertian partisipasi sendiri sangat beragam. Dalam konteks ini, partisipasi di artikan sebagai keterlibatan masyarakat secara aktif dalam setiap tahapan pembangunan mulai dari perencanaan hingga pelaksanaan. Masyarakat tidak lagi menjadi objek dari pembangunan tetapi menjadi subjek pembangunan, dimana masyarakat berperan dalam menyampaikan aspirasi, menentukan pilihan, memanfaatkan peluang dan menyelesaikan masalahnya ${ }^{1}$

Partispasi masyarakat merupakan suatu proses yang dapat mendukung masyarakat untuk mulai "sadar" akan situasi dan masalah yang dihadapinya serta berupaya mencari jalan keluar yangdapat dipakai untuk mengatasi masalah mereka (memiliki kesadaran kritis). Sumardi (2010:46), mengemukakan bahwa partisipasi adlah peran serta seseorang atau kelompok masyarakat dalam proses pembangunan baik dalam bentuk pernyataan maupun dalam bentuk kegiatan dengan memberi masukan pikiran, tenaga, waktu, keahlian, modal, dan atau materi, serta ikut memanfaatkan dan menikmati hasil-hasil pembangunan. ${ }^{2}$ 
.Dalam Undang-Undang No. 25 Tahun 2004 Sistem Perencanaan Pembangunan Nasional mengartikan "partisipasi masyarakat adalah keikutsertaan masyarakat untuk mengakomodasikan kepentingan mereka dalam proses penyusunan rencana pembangunan". ${ }^{3}$

Dalam penyelenggaraan pembangunan desa diperlukan pengorganisa-sian yang mampu menggerakkan masyarakat untuk mampu berpartisipasi dalam melaksanakan pembangunan desa serta melaksanakan administrasi pembangunan desa. Dengan demikian diharapkan pembangunan dan pelaksanaan administrasi desa akan berjalan lebih baik, tidak hanya didasarkan pada tuntutan emosional yang sulit dipertanggungjawabkan kebenarannya. Hal ini mengisyarakatkan bahwa keikutsertaan masyarakat di dalam perencanaan pembangunan desa memang benarbenar sangat dibutuhkan untuk mensinkronkan rencana pembangunan desa yang akan dilaksanakan dengan apa yang dibutuhkan masyarakat dalam meningkatkan kehidupan dan penghidupannya di desa. Karena bila tidak demikian, bisa saja pembangunan tersebut tidak sesuai dengan kebutuhan masyarakat yang bersangkutan sehingga pembangunan yang dilaksanakan sia-sia belaka dan masyarakat sendiri pun akan bersifat apatis terhadap pelaksanaan perencanaan pembangunan desa. ${ }^{4}$

Dengan adanya peran partisipasi masyarakat maka hasil dari pembangunan yang dilakukan nantinya diharapkan dapat sesuai dengan keinginan dan kebutuhan dari masyarakat.Pembangunan tidak pernah tercapai tujuannya jika selalu meninggalkan masyarakat, pembangunan akan dinilai berhasil jika pembangunan tersebut membawa sebuah perubahan kesejahteraan dalam masyarakat, sehingga proses pembangunan merupakan proses tawar menawar antar kebutuhan masyarakat dengan keinginan pemerintah. Oleh karena itu dalam pelaksanaan pembangunan partisipasi masyarakat merupakan hal yang sangat mempengaruhi keberhasilan proses pembangunan itu sendiri. ${ }^{4}$

Sistem perencanaan pembangunan nasional Indonesia yang dengan pendekataan top down dan Bottom up, nampaknya akan menjamin adanya keseimbangan antara prioritas nasional dengan aspirasi lokal dalam perencanaan pembangunan daerah. Namun yang terjadi banyak daerah belum sepenuhnya mengakomodasi aspirasi lokal, karena sebagian besar proposal yang diajukan berdasarkan aspirasi lokal telah tersingkir dalam rapat koordinasi yang menempatkan proposal yang diakan tingkatan pemerintahan yang lebih tinggi tanpa memperhatikan proposal yang diajukan oleh tingkat pemerintahan dibawahnya. Akibatnya, proposal akhir yang masuk ke pusat biasanya di dominasi oleh program yang diajukan oleh level pemerintahan yang lebih tinggi. ${ }^{5}$

Musrenbang merupakan wahana untuk mensinkronisasikan pendekatan "top down" dengan "bottom up" pendekatan penilaian kebutuhan masyarakat dengan penilaian yang bersifat teknis. Musrenbang adalah wahana publik yang penting untuk membawa stakeholder memahami isu isu dan permasalahan daerah mencapai kesepakatan atas prioritas pembangunan, dan konsesus untuk pemecahan berbagai masalah pembangunan daerah. ${ }^{5}$

Oleh karena itu pemerintahan memberikan perhatian terhadap pelaksanaan pembangunan desa seperti dalam Undang-Undang No 6 Tahun 2014 agar dapat 
memberikan hasil nyata, dalam arti adanya peningkatan taraf hidup masyarakat di suatu pihak dan pada pihak lain, munculnya semangat atau gairah membangun dari masyarakat yang diwujudkan dalam bentuk partisipasi masyarakat dengan ikut berpartisipasi dalam kegiatan-kegiatan pembangunan(A. Mustanir and Rusdi 2019) (A. Mustanir and Jaya 2016) (A. Mustanir and Jusman 2016) (A. D. Mustanir 2016) (A. Mustanir 2016). ${ }^{1}$

Perlunya keterlibatan masyarakat ini dianggap sangat penting,karena pembangunan yang terlalu menekankan peranan pemerintahan birokrasi (bercirikan top down) mendapat kritikan taja dimana kurang peka terhadap kebutuhan (A. Mustanir 2018)(A. Mustanir 2017). ${ }^{1}$

berdasarkan uraian diatas maka peneliti menemukan beberapa masalah yaitu:1. Bagaimana tingkat partisipasi masyarakat dalam musyawarah rencanan pembangunan didesa sipodeceng 2.faktor - faktor apa yang berpengaruh terhadap partisipasi masyarakat dalam musyawarah perencanaan pembangunan di desa sipodeceng kecamatan baranti .

Berdasarkan permasalah tersebut diatas sehingga peneliti untuk melakukan penelitian dan menuangkan hasil penelitian tersebut dengan judul penelitian yaitu "partisipasi masyarakat dalam musyawarah perencanaan pembangunan di desa sipodeceng kecamatan bararti "

\section{B.TINJAUAN PUSTAKA}

\section{1.partisipasi masyarakat}

Menurut (Isbandi, 2007) partisipasi masyarakat adalah keikutsertaan masyarakat dalam proses pengidentifikasian masalah dan potensi yang ada di dalam masyarakat, pemililihan dan pengambilan keputusan tentang alternatif solusi untuk menangani masalah, pelaksanaan upaya mengatasi masalah, dan keterlibatan masyarakat dalam proses mengevaluasi perubahan yang terjadi. Sedangkan (Adisamita, 2006) dan Slamet dalam (Mustanir, Lubis, and Barisan 2017) partisipasi anggota masyarakat adalah keterlibatan anggota masyarakat dalam proses perencanaan dan implementasi program pengembangan yang dilakukan di dalam masyarakat. ${ }^{4}$

MenuruBt Suryono dalam (Mustanir, Yasin, et al. 2018) partisipasi masyarakat dalam pembangunan diartikan sebagai ikut serta masyarakat dalam pembangunan, ikut dalam kegiatan pembangunan dan ikut serta pemanfaatan dan menikmati hasil-hasil pembangunan. ${ }^{4}$

Menurut Adisasmita (2006:41) Partisipasi Masyarakat adalah pemberdayaan masyarakat, peran sertanya dalam kegiatan penyusunan perencanaan implementasi program/proyek pembangunan, dan merupakan aktualisasi dan kesediaan dan kemauan masyarakat untuk berkorban dan berkontribusi terhadap implementasi Program Pembangunan. ${ }^{6}$

Menurut (A. Mustanir, Yasin, et al. 2018) terdapat beberapa pengertian dasar mengenai partisipasi masyarakat, di antaranya adalah sebagai berikut 
1) Partisipasi masyarakat adalah peran serta masyarakat dalam berbagai kegiatan individu, kelompok atau badan hukum yang timbul atas kehendak dan keinginan sendiri ditengahmasyarakat, untuk berminat dan bergerak di penyelenggaraan penataan ruang (Barisan, Ramadhan, and Mustanir 2017) (A.Mustanir and Rusdi 2019).

2) Partisispasi masyarakat adalah keterlibatan masyarakat sesuai dengan hak dan kewajibannya sebagai obyek dan subjek pembangunan, keterlibatan dalam tahap pembangunan dimulai sejak tahap perencanaan sampai pengawasan berikut segala hak dan tanggun jawabnya (A. Mustanir 2016) (A. Mustanir,Justira, et al. 2018). ${ }^{7}$

Isbandi dalam (Mustanir,Abadi, \& Nasri, 2016; Mustanir, Ali, \& Yasin, 2018; Uceng, Ali, Mustanir, \& Nirmawati, 2019; Uceng, Erfina, Mustanir, \& Sukri, 2919) mengatakan bahwa konsep partisipasi juga meliputi : Partisipasi mengenai hak politik, termasuk didalam pengambilam kebijakan publik, dilakukan secara sistemik, sebagai instrumen yang mendorong tata pemerintahan yang baik, serta dapat meningkatkan kepercayaan masyarakat terhadap penyelenggaraan pemerintahan. ${ }^{8}$

\section{Musyawarah Perencanaan Pembangunan}

Musrenbang adalah sebuah mekanisme perencanaan, sebuah institusi perencana yang ada di daerah dan sebagai mekanisme untuk mempertemukan usulan/kebutuhan masyarakat (bottom up planning) dengan apa yang akan diprogram pemerintah (tp down planning)(A. Mustanir 2018b) (A. Mustanir 2017). ${ }^{9}$

Musrenbang adalah forum-forum multi-pihak terbuka yang secara bersama mengidentifikasi dan menentukan prioritas kebijakan pembangunan masyarakat. Musyawarah perencanaan pembangunan (musrenbang) kelurahan adalah forum musyawarah tahunan para pemangku kepentingan (stakeholders) kelurahan untuk menyepakati rencana kerja kelurahantahun anggaran berikutnya. Tim Kerja Buku Panduan Penyelenggaraan Musrenbang dalam Ahmad Mustanir (2016). ${ }^{10}$

Musyawarah rencana pembangunan merupakan Perencanaan Pembangunan Bersama Masyarakat adalah panduan atau model pembangunan kelurahan yang menitikberatkan pada peran serta masyarakat dalam keseluruhan proses pembangunan. Pendekatan ini dilandasi oleh nilai-nilai dan semangat gotongroyong yang telah mengakar dalam budaya masyarakat Indonesia. Gotong-royong bertumpu pada keyakinan bahwa setiap warga masyarakat memiliki hak untuk memutuskan dan merencanakan apa yang terbaik bagi diri dan lingkungan serta cara terbaik dalam upaya mewujudkannya ${ }^{3}$

\section{Faktor-Faktor Yang Mempengaruhi Partisipasi Masyarakat dalam Musrenbang}

Faktor-faktor yang mempengaruhi partisipasi masyarakat dalam musrenbang antara lain adalah:

1. Faktor lingkungan fisik, mencakup; kesuburan tanah, jenis tanah, iklim, topografi dan orbitasi daerah. 
2. Faktor sosial ekonomi, mencakup; jenis pekerjaan, tingkat pendapatan, tingkat pendidikan, status pemilikan rumah / lahan, jumlah tanggungan keluarga, jumlah tenaga kerja keluarga dan tingkat kesehatan.

3. Faktor sosial budaya, mencakup; norma, nilai kepercayaan, pengetahuan, sikap, status pernikahan, usia, jenis kelamin, dan simbol-simbol.

4. Faktor policy pemerintah, mencakup; sifat-sifat koordinasi kepemimpinan lembaga sosial, pendekatan untuk memonitor masyarakat dan tingkat kebebasan untuk menyatukan pendapat dan keinginan.

Bukan sesuatu hal yang mudah untuk menerapkan kata partisipasi terutama pada suatu lingkungan masyarakat tertentu dikarenakan faktor-faktor tersebut. ${ }^{5}$

Slamet (2002:13), mengemukakan bahwa ada beberapa faktor yang mempengaruhi partisipasi masyarakat dalam musyawarah rencana pembangunan (musrenbang) antara lain adalah faktor sosial budaya yang mencakup: norma, nilai kepercayaan, dan sikap. Bukan sesuatu hal yang mudah untuk menerapkan partisipasi terutama pada suatu lingkungan masyarakat tertentu dikarenakan faktorfaktor tersebut. Sehingga prinsip-prinsip partisipasi harus memperhatikan kebersamaan, tumbuh dari bawah (bottom up) dan kepercayaan dan keterbukaan. ${ }^{7}$

\section{C.METODOLOGI}

Penelitian ini menggambarkan tipe kualitatif dan jenis penelitian menggunakan deskriptik karena akan memberikan gambaran keadaan dari objek penelitian sesuai dengan yang ada dilapangan tentang musyawarah perencanaan pembangunan (musrenbang) didesa terhadap partisipasi masyarakat dan menggunakan aplikasi Nvivo .Jadi penelitian ini menggambarkan analisis partisipasi masyarakat dalam musyawarah perencanaan pembangunan serta faktor faktor yang mempengaruhi partisipasi masyarakat di desa sipodeceng dikecamatan baranti kabupaten sidrap .

Populasi dalam penelitian ini adalah sebanyak 1637 kepala keluarga dari keseluruhan jumlah penduduk,yang berdasarkan sumber data yang ada .dimana Teknik penarikan sampel yang digunakan adalah non porobability sampling yaitu dengan purposive sampling

Teknik pengumpulan data dalam penelitian ini adalah observasi ,dan study literatur review (libray research). Pendekatan yang digunakan pada penelitian ini yaitu dengan menggunakan pendekatan literature. Dalam melakukan pengumpulan data penelitian mengumpulkan data dan sumber informasi yang berhubungan dengan partisipasi masyarakat dalam musyawarah perencanaan pembangunan desa melalui data data pendukung yang bersumber dari jurnal penelitian ,artikel,bukubuku penunjang, surat kabar dan majalah,ulasan ,rangkuman dan pemikiran penulis tentang beberapa sumber Pustaka (slide ,informasi dari internet,data gambar dan grafik dan lain lain)tentang topik yang dibahas (Hariyanti \& Wirapraja)

\section{D.HASIL DAN PEMBAHASAN}

Pelaksanaan partisipasi masyarakat dalam musrenbang di Desa sipodeceng difokuskan untuk menilai seberapa partisipasinya masyarakat dalam proses 
pembangunan yang terlibat seluruh unsur dan masyarakat yang akan menanggung.pelaksanaan pembangunan di desa sipodeceng sudah berpartisipsi dan melibabkan semua kelompok masyarakat dalam pembangunan .tingkat partisipasi masyarakat di desa sipodeceng baik dari segi kehadiran masyarakat yang mengikuti rapat .bukan dari pengamatan deskriptif pembangunan didesa sipodeceng sejauh ini mampu merealisasikan banyak usulan .

Masyarakat desa sipodeceng dimana masyarakat ikut peran dalam pelaksanaan pembangunan masyarakat desa sipodeceng juga memiliki kesadaran yang tinggi karena mereka menganggap bahwa hasil dari pelaksanaan tersebut ,karena mereka yang akan menikmatinya. Partisipasi masyarakat dalam pembangunan memerlukan rangsangan dari pemerintah desa karna pada hakikatnya partisipasi masyarakat dalam pembangunan ini diletatkan sebagai konsep yang bersistem .bahkan merupakan hak dasar masyarakat untuk terlibat secara kreatif dalam proses perencanaan serta dalam menikmatihasil hasil pembangunansecara adil dan manusiawi.

Adapun faktor penghambat dalam pelaksanaan pembangunan dimana adanya masyarakat yang hanya menyelesaikan Pendidikan sekedar sampai sekolah dasar atau menengah dan Adapun Sebagian yang buta huruf sehingga mereka tidak mampu memhami permasalahan yang akan dibahas .akan tetapi didesa sipodeceng akan terjung kelapangan untuk melakukan sosialisasi mengenai rencana pembangunan dan memberikan pemahaman kepada masarakat yg kurang memahami .

\section{E.KESIMPULAN}

Dari pembahasan tersebut dapat disimpulkan bahwa

1. tingkat partisipasi masyarakat di desa sipodeceng baik dari segi kehadiran masyarakat yang mengikuti rapat

2. Partisipasi masyarakat dalam pembangunan memerlukan rangsangan dari pemerintah desa karna pada hakikatnya partisipasi masyarakat dalam pembangunan ini diletatkan sebagai konsep yang bersistem

3. masyarakat ikut peran dalam pelaksanaan pembangunan masyarakat desa sipodeceng juga memiliki kesadaran yang tinggi karena mereka menganggap bahwa hasil dari pelaksanaan tersebut ,karena mereka yang akan menikmatinya.

\section{DAFTAR PUSTAKA}

1. Mustanir A, Dema H, Syarifuddin H, Irwan, Wulandari KMS. Pengaruh motivasi dan partisipasi masyarakat terhadap pembangunan di kelurahan lalebata kecamatan panca rijang kabupaten sidenreng rappang. Clean Gov. 2018;2(1):27-39.

2. Sulaeman Z, Mustanir A, Muchtar AI. Partisipasi masyarakat terhadap perwujudan good governance di desa damai kecamatan watang sidenreng kabupaten sidenreng rappang. 2019;7(3):88-92. Partisipasi Masyarakat, Good governance. 
3. Mustanir A, Razak MRR. Nilai Sosial Budaya Pada Partisipasi Masyarakat Etnik Towani Tolotang Dalam Musyawarah Rencana Pembangunan. 2017;(September):8-9.

4. Mustanir A, S F, Adri K, Nurnawati AA, Goso G. Sinergitas Peran Pemerintah Desa dan Partisipasi Masyarakat Terhadap Perencanaan Pembangunan di Kabupaten Sidenreng Rappang. Gov Sci. 2020;1(2):84-108.

5. Mustanir A, Abadi P. Partisipasi masyarakat dalam musyawarah rencana pembangunan di kelurahan kanyuara kecamatan watang sidenreng kabupaten sidenreng rappang. Polit Profetik. 2017;5(2):248-261.

6. Mustanir A, Yasin A. Transect Pada Perencanaan Pembangunan Partisipatif. Ilm Ilmu Adm Publik. 2018;8(2):21-31.

7. Mustanir A, Madaling, Uceng A, Kasau MNR, Barisan, Andriani D. karakteristik kepemimpinan lurah terhadap partisipasi masyarakat dalam musyawarah perencanaan pembangunan di Kelurahan Duampanua Kecamatan Baranti Kabupaten Sidenreng Rappang. Ilm Clean Gov. 2019;2(2):145-172.

8. Latif A, Irwan, Mustanir A. Analisis Kepemimpinan Terhadap Optimalisasi Masyarakat Pada Perencanaan Pembangunan Di Enrekang. Anal Kebijak dan Pelayanan Publik. 2019;5(2):1-20.

9. Mustanir A, Sellang K, Ali A, Madaling, Mutmainna. peranan aparatur pemerintah desa dan partisipasi masyarakat Dalam Musyawarah Perencanaan Pembangunan di Desa Tonrongnge Kecamatan Baranti Kabupaten Sidenreng Rappang. Ilm Clean Gov. 2018;2(1):67-84.

10. Mustanir A, Rusdi M. Participatory Rural Appraisal (PRA ) Sebagai Sarana Dakwah Muhammadiyah Pada Perencanaan Pembangunan Di Kabupaten Sidenreng Rappang. 2018:1-9. 